\title{
Long-term effects of fire on sage grouse habitat
}

\author{
PAMELA J. NELLE, KERRY P. REESE, AND JOHN W. CONNELLY
}

Authors are former research assistant and professor, Department of Fish and Wildife Resources, University of Idaho, Moscow, Ida, 83844; and principal wildife research biologist, Idaho Department of Fish and Game, 1345 Barton Rd, Pocatello, Ida, 83204

\begin{abstract}
This study documented the long-term ( $>10$ years) impact of fire on sage grouse (Centrocercus urophasianus Bonaparte) nesting and brood-rearing habitats on the Upper Snake River Plain in southeastern Idaho. The habitat of the study area is primarily mountain big sagebrush (Artemisia tridentata vaseyana Rydb.)grassland. Twenty different-aged burns were sampled from 1996 to 1997 , ranging from wildfires which burned during the 1960s to prescribed fires set during the 1990s. Canopy coverage and height of vegetation, and relative abundance of invertebrates, were estimated at burned and unburned sites within burns. Fourteen years after burning, sagebrush had not returned to preburn conditions. No difference was detected in forb abundance between different-aged burns. Relative abundance of ants and beetles was significantly greater in the 1-year old burn category but had returned to unburned levels by 3-5 years postburn. No benefits for sage grouse occurred as a result of burning sage grouse nesting and brood-rearing habitats. Burning created a long-term negative impact on nesting habitat because sagebrush required over 20 years of postburn growth for percent canopy cover to become sufficient for nesting.
\end{abstract}

Key Words: brood-rearing, Centrocercus urophasianus, nesting, sagebrush

Sage grouse (Centrocercus urophasianus Bonaparte) populations have declined across their entire range over the past 30 years (Connelly and Braun 1997). Sage grouse require sagebrush (Artemisia spp.) habitats at every stage of their life cycle (Patterson 1952) and the conversion of sagebrush rangeland to grassland for livestock grazing or for crop production has led to widespread loss, degradation, and fragmentation of sage grouse habitat (Braun et al. 1977). Currently, prescribed fire is a popular tool for removing sagebrush to increase forage production for livestock (Peterson 1995).

Several researchers studied short-term effects of fire on sage grouse habitat (Connelly et al. 1981, Gates 1985, Martin 1990, Benson et al. 1991, Robertson 1991, Fischer 1994), but no researcher has addressed longer-term (> 10 years) effects. During the first few years after burning, nesting habitat is essentially

Funding was provided by the U.S. Bureau of Land Management (BLM) and the Idaho Department of Fish and Game (IDFG). This is a contribution from Idaho Federal Aid in Wildlife Restoration Project W-160-R and Contribution 897 of the University of Idaho College of Forestry, Wildlife and Range Experiment Station.

We gratefully acknowledge D. Aslett, J. Hearshaw, A. Hilborn, A. Owsiak, and B. Vogt for their assistance in data collection. R.K. Steinhorst and C. Williams provided statistical advice.

Manuscript accepted 29 Jan. 2000.
Resumen

Este estudio documenta el impacto a largo plazo ( $>10$ años) del fuego en los habitas de anidamiento y crianza de polluelos de "Sage grouse" (Centrocercus urophasianus Bonaparte) en las planicies altas del ráo "Snake"en el sudeste de Idaho. El h·bitat del áea de estudio fue principalmente "Mountain big sagebrush"(Artemista tridentata vaseyana Rydb)—pastizal. De 1996 a 1997 se muestrearon 20 quemas de diferente edad, variando de fuegos naturales que ocurrieron durante la década de 1960 hasta quemas prescritas realizadas en la década de los 1990's. Se estimó la cobertura de la copa, la altura de la vegetación y la abundancia relativa de invertebrados en sitios quemados y no quemados dentro de las áeas incendiadas. 14 años después de la quema el "Sagebrush" no habáa regresado a las condiciones que se encontraba antes de la quema. No se detectaron diferencias en la abundancia de hierbas entre las áeas con diferente edad de quema. La abundancia relativa de hormigas y escarabajos fue significativamente mayor en las áeas con quemas de 1 año de antig,edad y 3-5 años después la población de estos insectos regreso a los niveles existentes antes de la quema. La quema del h.bitat de anidamiento y crianza de los polluelos "Sage grouse" no produce beneficio alguno para esta especie de ave. La quema produjo un impacto negativo a largo plazo en el h·bitat de anidamiento porque el "sagebrush"requirió mas de 20 años después de la quema para regenerar una cobertura de la copa suficiente para el anidamiento del "Sage Grouse".

destroyed and brood-rearing habitat is not improved. Prescribed burning may have different long-term effects as species diversity of vegetation and invertebrate food resources change with succession (Bendall 1974, Fischer et al. 1996), and could result in suboptimal habitat for sage grouse.

We investigated the long-term impact of fire on sage grouse nesting and brood-rearing habitats in Clark and Fremont counties in southeastern Idaho. At least 186,694 ha of sagebrush were treated by prescribed burning, spraying, plowing, reseeding and burned by wildfires in Clark, Fremont and Jefferson counties from the 1950s through 1994. A prescribed burning program was instituted in the 1980 s and removed 36,444 ha of sagebrush during the 1980s and 1990s, and wildfires (fires resulting from lightening strikes, humans accidentally or deliberately setting fires on private land that burned out of control), have burned 80,264 ha. Concurrently, the breeding population of migratory sage grouse in the study area declined significantly from the 1950s to the 1990s (Crowley and Connelly 1996). 


\section{Methods}

\section{Study Area and General Methods}

The study area, in southeastern Idaho on the Upper Snake River Plain in Clark and Fremont counties, encompassed approximately 40,000 ha $\left(44^{\circ} 00^{\prime} \mathrm{N}, 111^{\circ} 45^{\prime} \mathrm{W}\right)$. Ownership is divided among state, Bureau of Land Management, and private lands and includes parts of the Sand Creek Wildlife Management Area (WMA). Approximately 20,000 sheep and 1,660 cattle graze the area each year from May/June to September/October (G. Dawson, BLM, pers. comm.).

Mean spring and summer precipitation ranges from $20 \mathrm{~cm}$ on the southern end of the WMA to $46 \mathrm{~cm}$ in the north, and temperatures range from $4^{\circ} \mathrm{C}$ to $38^{\circ} \mathrm{C}$ during spring and summer (D. Aslett, IDFG, pers. comm.). Elevation ranges from approximately $1,430 \mathrm{~m}$ to buttes of $2,440 \mathrm{~m}$ (Crowley and Connelly 1996). Mountain big sagebrush (Artemisia tridentata vaseyana $\mathrm{Rydb}$.) is the most common sagebrush subspecies, but three-tipped sagebrush (A. tripartita Rydb.) occurs as well. Other shrubs include bitterbrush (Purshia tridentata (Pursh) DC.), rabbitbrush (Chrysothamnus spp. Nutt.), and horsebrush (Tetradymia canescens DC.). Sand dunes in the southern end of the study area support stands of chokecherry (Prunus virginiana L.). A variety of grasses and forbs occur, including arrowleaf balsamroot (Balsamorhiza sagittata (Pursh) Nutt.), tailcup lupine (Lupinus caudatus Kell.), bluebunch wheatgrass (Agropyron spicatum (Pursh) Scribn. \& Smith), thick-spiked wheatgrass (A. dasys tachyum (Hook) Scribn.) and Nevada bluegrass (Poa nevadensis Vasey) (Dalke et al. 1963).

By 1997, there were 8 wildfires and 12 prescribed burns in the study area (D. Aslett, IDFG, pers. comm., Crowley and Connelly 1996). Size and season of burn for the 4 oldest wildfires were not available, but mean size of 4 wildfires was 390 ha. Average size of 12 prescribed burns was 975 ha. We sampled the 20 burns from May through August during 1996 and 1997. Within unburned areas, vegetation was considered $\geq 37$ years old; in burned sites, age of vegetation was based on time-since-burned. Vegetation was classified as unburned if there was no visible sign of fire (blackened stumps and blackened standing dead sagebrush) and no record of it having burned in the past 37 years. We sampled burns from 1 to 6 years old in both 1996 and 1997. All other burns were sampled in either 1996 or
1997, and the year in which they were sampled was determined randomly. Because of the mosaic nature of burns in sagebrush, we randomly sampled 4 times within each burn, twice in burned vegetation and twice in unburned vegetation. We sampled every site twice each field season, with approximately 1 month between samples, to incorporate variations in plant phenology and invertebrate abundance as the season progressed. At each site we laid a 50-m tape, oriented north-south, to mark the sampling transect.

\section{Vegetation canopy cover and forb abundance}

We measured percent shrub cover by species with the line intercept method (Canfield 1941), and at 5-m intervals along the transect, we measured grass height $(\mathrm{cm})$ at the tape and the tallest sagebrush plant $(\mathrm{cm})$ within $1-\mathrm{m}$ radius of the tape. Forb composition and abundance were measured with a 2- x 5-dm frame (Daubenmire 1959), placed at 1-m intervals along the transect. We recorded the percent cover of grasses, litter and bare ground, and percent cover of the following forbs known to be important in the diet of sage grouse, associated with good broodrearing habitat, or indicators of disturbance: western yarrow (Achillea millefoli um L.), buckwheat (Eriogonum spp. Michx.), Phlox spp. L., false dandelion (Agoseris glauca (Pursh) Raf.), wild onion (Allium spp. L.), dandelion (Taraxacum officinale Weber), rosy pussytoes (Antennaria rosea Rybd.), death camas (Zygadenus venenosus Wats.), prickly pear (Opuntia polyacantha Haw.), sego lily (Calochortus spp. Pursh.), lupine (Lupinus spp.), prickly lettuce (Lactuca serriola L.), hawksbeard (Crepis spp. L.), common salsify (Tragapogon spp. L.), and prairie starflower (Lithophragma spp. Nutt.) (Klebenow and Gray 1968, Peterson 1970, Wallestad et al. 1975, Drut et al. 1994b, Pyle and Crawford 1996). We categorized these forbs as major forbs and other forbs encountered as miscellaneous forbs.

\section{Relative invertebrate abundance}

We used pitfall traps (modified from Fischer 1994) to sample the relative abundance of invertebrates within burns. Sixteen test tubes were sunk flush with the ground $50 \mathrm{~cm}$ apart in a $4 \times 4$ grid, located in a random direction 20 paces south of each vegetation transect. The test tubes were filled with a 1:1 solution of water and ethylene glycol and sealed with a cork until sampling began. During sampling, pitfalls were opened for 24 hours.
Invertebrates from all tubes at each grid were combined and stored in $70 \%$ alcohol. Invertebrates were separated into Hymenoptera (ants), Coleoptera (beetles), and Orthoptera (grasshoppers) in the laboratory, and all other invertebrates were categorized as miscellaneous. Samples were oven dried for 24 hours at $40^{\circ} \mathrm{C}$, and weighed to $0.01 \mathrm{~g}$.

\section{Statistical Analysis}

We used SAS (SAS Inst., Inc. 1988) and SPSS (SPSS Inc. 1992) to analyze the data and considered differences significant if $\mathrm{P}$ $\leq 0.05$. We transformed proportional data with the arcsine of the square root (Zar 1984) and plotted histograms to determine whether data were normally distributed. For univariate tests, we used the appropriate non-parametric test when data were non-normal. We were unable to determine whether or not vegetation had burned in areas categorized as burned by wildfire before the 1970s due to regrowth of vegetation. As a result we considered all vegetation from these sites as unburned. We pooled data between months and years for the prescribed burns from 1 to 6 -years old that were sampled in both years, and pooled data between months for all other transects that were sampled in either year. This pooling resulted in a total of 84 transects, 38 which were from burned vegetation and 46 from unburned vegetation.

We used an exploratory cluster analysis (Hair et al. 1995) to produce a natural structure of vegetation characteristics based on a multivariate profile, including 10 variables known to be important in nesting and brood-rearing habitats (Dalke et al. 1963, Wallestad 1971, Peterson 1970) and/or strongly affected by fire (Bunting 1985, Wright 1985). These were: (1) percent sagebrush cover, (2) percent bitterbrush cover, (3) percent cover of standing dead shrubs, (4) percent total live shrub cover, (5) sagebrush height in $\mathrm{cm}$, (6) grass height in $\mathrm{cm},(7)$ percent grass cover, (8) percent litter cover, (9) percent cover of major forbs, and (10) percent cover of miscellaneous forbs. The number of clusters chosen from the cluster analysis for use in subsequent analyses was based on the minimum number of clusters that were characterized by identifiable and useful (from a management perspective) vegetation age categories.

We used a confirmatory MANOVA (Hair et al. 1995) to establish that clusters were statistically distinct and report the $\mathrm{P}$ values as descriptive measures of these differences. We used a Kruskal-Wallace one-way analysis of variance (Zar 1984) 
Table 1. Characteristics of different-aged burn clusters from the Upper Snake River Plain, SE Idaho, 1996-1997.

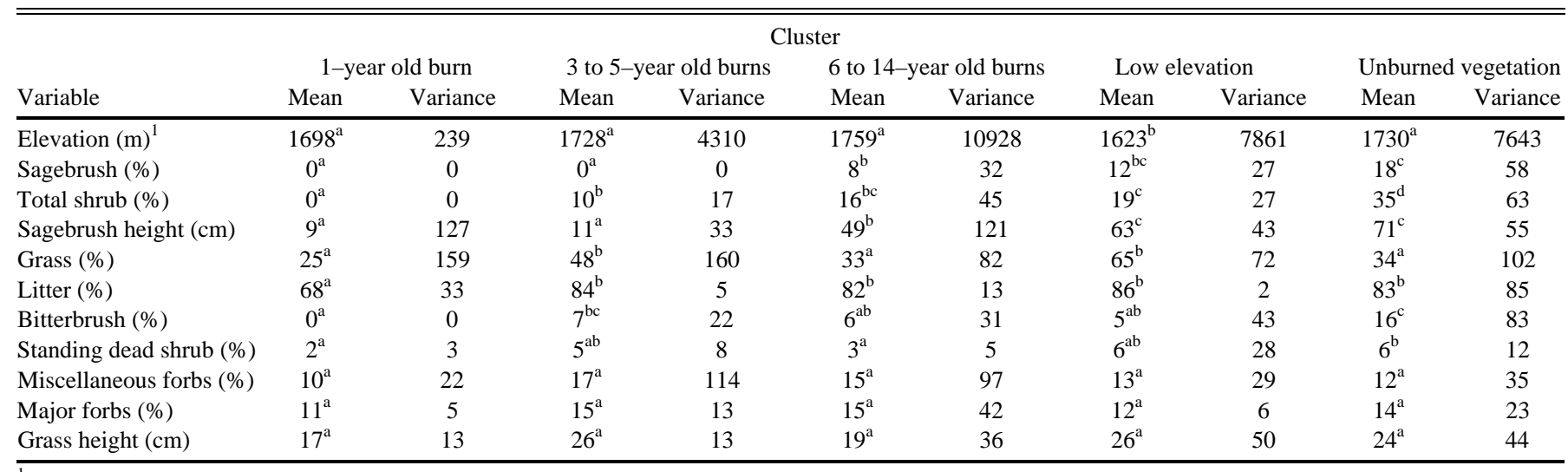

${ }^{1}$ Within row means significantly different at $\propto=0.05$ have different letters.

to test whether the 6 forbs identified in the literature as the most important food items in sage grouse diet (common yarrow, sego lily, hawksbeard, prickly lettuce, dandelion and yellow salsify) (Peterson 1970, Wallestad et al. 1975) differed in abundance among different-aged burns.

We used the same grouping of transects suggested by the vegetation cluster analysis to analyze the invertebrate data and used a MANOVA (Hair et al. 1995) to test if relative invertebrate abundance differed among different-aged burns. In both MANOVA's we used Pillai's trace statistic as the test statistic, Tukey's multiple comparison test (Zar 1984) for post-hoc comparisons, and a canonical analysis (Hair et al. 1995) to determine which variables were most important in separating clusters.

\section{Results}

\section{Cluster composition}

We selected 5 clusters for analyses and excluded 1 transect that did not enter a cluster. We described clusters according to the age of the majority of the vegetation in each cluster. Four relatively distinct age classes emerged, although clusters included transects from burns older or younger than the age class used to identify the cluster. One cluster was difficult to describe with respect to vegetation age and other criteria, such as elevation and soil, were used to characterize it.

The first cluster $(n=5)$ contained characteristic post-disturbance vegetation, with an absence of shrub cover and an increase in canopy cover of aggressive colonizers such as the dandelion tribe (Taraxacum officinale and Agoseris spp.). Four of the 5 transects were from 1-year old burns and the remaining transect was from a 14-year old burn. The second cluster $(n=9)$ was representative of an early seral stage. Facultative seral species such as western yarrow and rosy pussytoes had increased in canopy cover, and bitterbrush had begun to return. Eight transects came from burns ranging from 3 to 5 -years old, and the remaining transect was from a 27-year old burn. The third cluster $(n=16)$ contained 11 vegetation transects ranging from 6 to 14-years old, and was representative of mid-seral vegetation. Sagebrush had begun to contribute to the shrub cover, there was a decrease in canopy cover of some early seral stage forbs, such as dandelion, false dandelion and western yarrow, and forbs typically damaged by fire, such as Eriogonum, had increased in canopy cover. This group also contained 3 transects from unburned vegetation 36 years old, and 2 transects from younger burns (4 and 5 years old). The largest clus ter $(n=48)$ comprised 40 unburned vegetation transects 36 to 37 -years old and was representative of late seral vegetation, with sagebrush and bitterbrush at their greatest canopy cover. Within this cluster 8 transects were from burned vegetation 12 to 27 -years old. The last cluster $(n=5)$ contained 2 unburned vegetation transects 36 years old, 2 transects from 10-year old burns, and 1 transect from a 16-year old burn. This cluster was difficult to characterize by vegetation age, but all transects were from the lowest elevations sampled. These 5 transects also had very sandy soil, were heavily grazed by cattle and sheep, and were some of the most southerly and westerly sites sampled. In total, $73(88 \%)$ of 83 transects clustered as expected based on years since burned.

\section{Effect of time-since-burned on vegetation}

Vegetation characteristics differed $(\mathrm{F}=$ $8.95, \mathrm{P}=0.0001$ ) among burns based on the 10 variables selected for the cluster analysis, plus elevation. The first canonical variable described $80 \%$ of the variation in the data. Sagebrush height and percent canopy cover, percent total shrub cover, and percent grass cover were primarily responsible for the separation of clusters with canonical coefficients of $1.82,0.72$, 0.65 , and -0.58 , respectively. The absolute value of all other canonical coefficients was $<0.39$. Percent grass cover was inversely related to sagebrush height and cover and to total shrub cover.

All variables in the univariate tests differed $(\mathrm{P} \leq 0.05)$ among the 5 vegetation clusters, except for percent cover of the major and miscellaneous forbs and grass height (Table 1). Sagebrush canopy cover was less in 1-year old burns, 3 to 5-year old burns and 6 to 14-year old burns than in unburned vegetation. Low elevation sites did not differ in sagebrush canopy cover from unburned vegetation and 6 to 14-year old burns but had more sagebrush than younger aged burns. Total shrub cover was greater in unburned vegetation than in all other clusters, and unburned vegetation had taller sagebrush shrubs compared with all other clusters except the low elevation sites. The 1-year old burns and 3 to 5-year old burns did not differ in sagebrush shrub height, but both had smaller sagebrush shrubs than 6 to14-year old burns.

Grass cover in 3 to 5 -year old burns and low elevation sites was greater than grass cover in 1-year old burns, 6 to 14-year old burns and unburned vegetation, among which there was no difference in grass cover. Litter cover did not differ among clusters, except in 1-year old burns which was lower compared to all other clusters

Bitterbrush canopy cover was less in 1year old burns compared with 3 to 5-year old burns and unburned vegetation. Unburned vegetation had more bitterbrush 
Table 2. Composition of major sage grouse food forbs in different-aged burn clusters, Upper Snake River Plain, SE Idaho, 1996-1997.

\begin{tabular}{lcccccc}
\hline \hline Forb genera & $\begin{array}{c}\text { 1-year old } \\
\text { burn }\end{array}$ & $\begin{array}{c}3 \text { to 5-year } \\
\text { old burns }\end{array}$ & $\begin{array}{c}\text { 6 to 14-year } \\
\text { old burns }\end{array}$ & $\begin{array}{c}\text { Low } \\
\text { elevation }\end{array}$ & Unburned & P \\
\hline Achillea & $0.57^{1}$ & 1.73 & 1.08 & 0.84 & 1.12 & 0.11 \\
Calochortus & 0 & 0 & 0 & 0.51 & 0 & 0.28 \\
Crepis & 0 & 0 & 0.53 & 0.51 & 0.52 & 0.23 \\
Lactuca & 0 & 0.54 & 0.69 & 0.57 & 0.57 & 0.41 \\
Taraxacum & 1.47 & 1.18 & 0.84 & 1.63 & 0.76 & 0.07 \\
Tragapogon & 0.68 & 0.57 & 0.59 & 0.93 & 0.58 & 0.06 \\
\hline
\end{tabular}

${ }^{1}$ Mean percent canopy cover of each forb in different-aged burn clusters.

than other clusters, except burns from 3 to 5 -years old. However, this is probably a result of high variance in 3 to 5 -year old sites and unburned sites. The 1-year old burns and 6 to 14-year old burns had less standing dead shrub cover than unburned vegetation.

The abundance of major and miscellaneous forbs was similar among clusters (Table 1). Major food items, common yarrow, lily, hawksbeard, prickly lettuce, dandelion and yellow salsify, did not differ in abundance among different-aged burns (Table 2).

\section{Effect of time-since-burned on invertebrate relative abundance}

Relative abundance of invertebrates, measured as dry weight in grams, differed among vegetation age clusters $(\mathrm{F}=3.16, \mathrm{P}$ $=0.001$ ), and we rejected the null hypothesis that there was no effect of time-sinceburned on invertebrate abundance. A canonical analysis revealed that relative abundance of beetles was most influential in separating clusters. In univariate tests, relative abundance of ants and beetles differed among vegetation age clusters (Table 3). There were significantly more beetles in 1-year old burns than in all other age clusters. The 1-year old burns also contained more ants than 3 to 5-year old burns and unburned vegetation, but there was no difference in the relative abundance of grasshoppers or miscellaneous invertebrates among different-aged burns.

\section{Discussion}

Response of vegetation to fire can vary considerably because of differences in topography, slope, fine fuel load, moisture content of vegetation, fire intensity, season of burn and postburn climatic conditions (Daubenmire 1968, Winward 1985). Inherent variation in vegetation responses to burning can render predicting the longterm effects of fire difficult. Ten transects were not clustered as expected based on years since burned. This finding possibly resulted from variations in vegetation due to topography, grazing pressure, post-climatic conditions or fire intensity. For example, transects from young burns clustered with older burns may have been due to rapid recovery from low-severity fires. Transects from older burns clustered with younger burns could be a result of heavy grazing pressure. Despite many factors contributing to variable responses of vegetation to fire, some clear long-term effects of fire upon sage grouse habitat were detected on the Upper Snake River Plain.

Except for occasional sprouting by threetip and silver sage (A. cana, which was not present within the study area), sagebrush species are nonsprouters and are easily killed by fire (Tisdale and Hironaka 1981, Blaisdell et al. 1982). Although sagebrush was beginning to re-establish in 6 to 14-year old burns on the Upper Snake River Plain, mean sagebrush canopy cover 14 years postburn was less than one-half that of unburned vegetation and mean sagebrush height was $69 \%$ of unburned vegetation. In general, mountain big sagebrush usually re-establishes within 5 to 10 years (Winward 1985), and may return to preburn density and cover within 15 to 20 years postburn (Bunting et al. 1987). However, severe fires can slow re-establishment, so that sagebrush takes longer to recover and dominate an area (Bunting et al. 1987). This factor may explain why sagebrush in many burns on the Upper Snake River Plain took relatively longer to return to preburn levels. After a severe fire on the US Sheep Experimental Station in southeastern Idaho, 30 years passed before sagebrush was once again the dominant species (Blaisdell et al. 1982).

Eighty-six percent of transects from 36year old burns were clustered with unburned vegetation, suggesting that 36 years is sufficient time to recover. Our ability to more precisely define how long vegetation takes to return to preburn conditions on the Upper Snake River Plain was limited by the lack of burns 20 to 30 years old. Even though 3 of the 4 transects from fires between 20 and 30 years old were clustered with unburned vegetation, it is not possible to conclude that this is sufficient time for all burned areas to return to preburn conditions. These 3 transects may have recovered sooner than average due to other influences, such as being lightly burned and/or having favorable postburn climatic conditions. Information from burn reports provided little help in resolving these questions.

Removing the shrub component through fire may allow grasses and forbs to increase in productivity and abundance. In general, total herbage production of grasses reaches a maximum 2 to 5 years after burning, after which it declines as sagebrush and other shrub species increase (Blaisdell et al. 1982, Bunting 1985). In short-term studies, Martin (1990) found significantly more grass cover 2 years postburn, but Pyle and Crawford (1996) reported a significant reduction in total grass cover 1 year postburn, and no differ-

Table 3. Dry weight of invertebrates in different-aged burn clusters, Upper Snake River Plain, SE Idaho, 1996-1997.

\begin{tabular}{|c|c|c|c|c|c|c|c|c|c|c|}
\hline \multicolumn{11}{|c|}{ Cluster } \\
\hline \multirow[b]{2}{*}{ Variable } & \multicolumn{2}{|c|}{$\begin{array}{l}\text { 1-year old burn } \\
\qquad(n=5)\end{array}$} & \multicolumn{2}{|c|}{$\begin{array}{l}3 \text { to 5-year old burns } \\
\qquad(\mathrm{n}=9)\end{array}$} & \multicolumn{2}{|c|}{$\begin{array}{l}6 \text { to } 14-\text { year old burns } \\
(n=16)\end{array}$} & \multicolumn{2}{|c|}{$\begin{array}{l}\text { Low elevation } \\
\qquad(\mathrm{n}=5)\end{array}$} & \multicolumn{2}{|c|}{$\begin{array}{l}\text { Unburned vegetation } \\
\qquad(\mathrm{n}=48)\end{array}$} \\
\hline & Mean & Variance & Mean & Variance & Mean & Variance & Mean & Variance & Mean & Variance \\
\hline & (g) & & (g) & & (g) & & (g) & & (g) & \\
\hline Ants ${ }^{1}$ & $0.46^{\mathrm{a}}$ & 0.40 & $0.08^{\mathrm{b}}$ & 0.01 & $0.15^{\mathrm{ab}}$ & 0.07 & $0.25^{\mathrm{ab}}$ & 0.09 & $0.09^{\mathrm{b}}$ & 0.02 \\
\hline Beetles & $1.7^{\mathrm{a}}$ & 1.36 & $0.39^{b}$ & 0.02 & $0.42^{\mathrm{b}}$ & 0.08 & $0.73^{\mathrm{b}}$ & 0.13 & $0.54^{\mathrm{b}}$ & 0.13 \\
\hline Grasshoppers & $0.81^{\mathrm{a}}$ & 0.58 & $0.28^{\mathrm{a}}$ & 0.05 & $1.22^{\mathrm{a}}$ & 8.1 & $0.13^{\mathrm{a}}$ & 0.02 & $0.42^{\mathrm{a}}$ & 0.83 \\
\hline Miscellaneous & $0.02^{\mathrm{a}}$ & 0.00 & $0.09^{\mathrm{a}}$ & 0.00 & $0.05^{\mathrm{a}}$ & 0.04 & $0.07^{\mathrm{a}}$ & 0.00 & $0.07^{\mathrm{a}}$ & 0.01 \\
\hline
\end{tabular}

${ }^{1}$ Within row means significantly different at a $=0.05$ have different letters. 
ence between treatment and controls 2 years postburn. Grass cover on the Upper Snake River Plain was greatest in 3 to 5year old burns, which had very sparse shrub cover and had returned to preburn levels by 6 to 14 years postburn as the shrub canopy cover increased.

Height and canopy cover of sagebrush and grass are important characteristics of sage grouse nest sites. Sage grouse need a minimum of $15 \%$ overall sagebrush canopy cover for successful nesting (Wallestad and Pyrah 1974). Height of nest shrubs ranges from $36 \mathrm{~cm}$ to $70 \mathrm{~cm}$ (Patterson 1952, Wallestad and Pyrah 1974, Rothenmaier 1979, Wakkinen 1990, Sveum et al. 1998), and sagebrush canopy cover at nests ranges from 15 to $40 \%$ (Klebenow 1969, Wallestad and Pyrah 1974, Braun et al. 1977, Rothenmaier 1979). Sagebrush canopy cover measured within a $1-\mathrm{m}^{2}$ plot at nest sites averaged $51 \%$ and $59 \%$ in a 2 year study in Washington by Sveum et al. (1998). Only unburned vegetation on the Upper Snake River Plain offered both sagebrush height and cover within the range of conditions most frequently used for nesting as reported in the literature. Sagebrush height was within the range used by nesting grouse by 6 to 14 years postburn, but sagebrush canopy cover (only $8 \%$ ) was insufficient for nesting. Insufficient sagebrush canopy cover may result in hens nesting under other shrub species. Hens have been found nesting under non-sagebrush shrubs (e.g. snowberry (Symphoricarpos oreophilus Gray), bitterbrush, rabbitbrush), but nesting success was lower compared to birds nesting under sagebrush (Connelly et al. 1991). Compared with the $20 \%$ to $40 \%$ total shrub canopy cover used by sage grouse (Braun et al. 1977), total shrub canopy cover in burns up to 14 years old on the Upper Snake River Plain did not provide adequate canopy for nesting.

Grass height and percent grass cover adequate for nesting occurred in nearly all burn clusters. Mean grass height at nests was reported at $19 \mathrm{~cm}$ (Wakkinen 1990, Connelly et al. 1991). Only 1-year old burns failed to provide sufficiently tall grass. Grass cover measured at nest sites ranges from $3.7 \%$ to $27 \%$ (Klebenow 1969, Wakkinen 1990, Connelly et al. 1991, Musil et al. 1994, Sveum et al. 1998), and percent grass cover in all burn clusters provided as much, or more, cover.

Brood-rearing occurs in a wide range of shrub heights and densities. Shrub heights at brood locations range from 15 to $37 \mathrm{~cm}$ (Martin 1970, Wallestad 1971). Sagebrush canopy cover ranges from $6 \%$ to $31 \%$ for feeding during the day (Klebenow 1969, Peterson 1970, Martin 1970, Wallestad 1971, Klott and Lindzey 1990), to denser cover and taller shrubs at night for roosting (Dunn and Braun 1986). Burns > 5years old on the Upper Snake River Plain provided shrubs of height and density within the range of conditions used by broods. While mean sagebrush heights in 6 to 14-year old burns and unburned vegetation may exceed $37 \mathrm{~cm}$, the variance of sagebrush heights in these clusters was large (Table 1), indicating that sagebrush of preferred heights occurred.

Brood-rearing habitat must provide forbs and insects for food. Total forb cover in the different-aged burns on the Upper Snake River Plain fell within or exceeded values reported in the literature as preferred broodrearing habitat, ranging from 12 to $14 \%$ (Drut et al. 1994a) to $17 \%$ (Klott and Lindsey 1990) to 22\% (Wallestad 1971). The abundance of major forbs and average grass height in the understory of unburned vegetation was similar to burned vegetation, and the increase in grass cover in burned vegetation was short-lived. In general, total herbage production of forbs reached a maximum 2 to 5 years postburn, after which it declined as sagebrush and other shrubs increased (Bunting 1985). Perennial forb cover, total forb cover, and total forb diversity increased during the second growing season after a fire in Oregon (Pyle and Crawford 1996), and forbs increased the first 2 years post fire in eastern Idaho (Martin 1990). Harniss and Murray (1973) found that forbs on burned plots maintained a greater biomass for 5 to 15 years after burning compared to control plots.

In contrast to the above studies, no significant difference in forb cover was detected among different-aged burns on the Upper Snake River Plain. This finding is similar to what Fischer et al. (1996) reported from a study of the effects of fire in the Wyoming sagebrush (A. tridentata wyomingensis Nutt.) habitat in southeastern Idaho, where forb cover was similar in burned and unburned habitat up to 3 years postburn. Fischer et al. (1996) concluded that drought conditions might have limited forb response to reduced shrub competition. The Upper Snake River Plain region also experienced drought conditions throughout much of the 1980s and early 1990s (D. Aslett, IDFG, pers. comm). Approximately 7,900 sheep graze the 3 to 5-year old burns from May/June through September/October each year (Greg Dawson, BLM, pers. comm.), and livestock may remove enough forb biomass so that postburn response was not detectable. The lack of forb response could be a combination of drought and livestock grazing (Coggins 1998).

Invertebrates are essential in the diet of sage grouse chicks (Patterson 1952, Klebenow and Gray 1968, Peterson 1970), and the amount of insects consumed is positively correlated with chick survival and growth (Johnson and Boyce 1990). We found no long-term effect of fire on invertebrate abundance. However, Fischer et al. (1996) found significantly fewer ants 2 to 3 years postburn in burned compared with unburned vegetation. The increase in Coleopteran abundance 1-year postburn on the Upper Snake River Plain has not been reported in other studies (Fischer et al. 1996, Pyle and Crawford 1996), although Rickard (1970) found that some Coleopteran species were less abundant in burned habitat compared with unburned habitat. The initial increase in ant and beetle abundance after a fire observed on the Upper Snake River Plain may be of limited value to sage grouse chicks because most shrub cover was removed, potentially increasing chick vulnerability to predation when foraging in open areas.

\section{Conclusions and Management Implications}

Burning to remove sagebrush on the Upper Snake River Plain is not justifiable as a sage grouse management practice because only unburned vegetation in the area offers suitable nesting habitat. No brush control work should occur where live sagebrush cover is less than $20 \%$ (Braun et al.1977), as it is in unburned vegetation on the Upper Snake River Plain.

Each burn may seem inconsequential in relation to the entire area of sagebrush habitat apparently available to sage grouse on the Upper Snake River Plain. However, the cumulative effect of burning upon critical nesting and brood-rearing habitats could be seriously detrimental to a sage grouse population if vegetation over a large area remains in sub-optimal conditions for many years. From 1980 through $1996,11,676$ ha were burned by prescribed fire, which accounted for approximately $29 \%$ of the study area, none of which is currently suitable nesting habitat and much of which is not good broodrearing habitat. Many of these burns are juxtaposed to create large contiguous areas of sub-optimal nesting habitat. Burn programs should be planned to avoid creating a landscape of adjacent young burns, especially of burns younger than 14-years old. Future research should involve mapping the 
pattern of burned/unburned sagebrush on the Upper Snake River Plain to better plan and implement future prescribed burns.

Scheduling when a habitat is burned should not be predetermined by the length of time since the area last burned. Although other studies suggest that sagebrush returns to preburn conditions by 15 years postburn (Bunting et al. 1987), our results demonstrate that this is not the case for sagebrush in the Upper Snake River Plain. By measuring 3 variables (sagebrush height, percent sagebrush canopy cover and percent total shrub cover) at permanent, randomly located transects within burned vegetation, a fast and efficient monitoring program to follow the recovery of vegetation could be implemented. The recovery of burned vegetation with respect to sage grouse nesting and brood-rearing requirements could then be evaluated.

\section{Literature Cited}

Bendall, J.F. 1974. Effects of fire on birds and mammals, pp. 73-138 In: T.T. Kozlowski and C.E. Ahlgren, (eds.), Fire and ecosystems. Academic Press, N.Y.

Benson, L.A., C.E. Braun, and W.C. Leininger. 1991. Sage grouse response to burning in the big sagebrush type. Proc. Issues and Tech. in the Manage. of Impacted Western Wildl. Thorne Ecol. Inst. 5:97-104.

Blaisdell, J.P., R.B. Murray, and E.D. McArthur. 1982. Managing Intermountain Rangelands-Sagebrush-Grass Ranges. USDA For. Serv. Gen. Tech. Rep. INT-134. 36pp.

Braun, C.E., T. Britt, and R.O. Wallestad. 1977. Guidelines for maintenance of sage grouse habitats. Wildl. Soc. Bull. 5:99-106.

Bunting, S.C. 1985. Fire in the sagebrush-grass ecosystems-Successional changes, pp. 7-11 In: Sanders, K., J. Durham, [and others] (eds.) Rangeland Fire Effects-proceedings of a symposium. USDI Bur. of Land Manage., Idaho State Office and Univ. of Idaho. 1985. Boise, Ida

Bunting, S.C., B.M. Kilgore, and C.L. Bushey. 1987. Guidelines for prescribed burning in sagebrush-grass rangelands in the Northern Great Basin. USDA For. Serv., Intermountain Res. Sta., Gen. Tech. Rep. INT-231. Ogden, Utah.

Canfield, R.H. 1941. Application of the line intercept method in sampling range vegetation. J. For. 39:388-394.

Coggins, K.A. 1998. Relationship between habitat changes and productivity of sage grouse at Hart Mountain National Antelope Refuge. M.S. Thesis. Oregon State Univ. Corvallis, Ore.

Connelly, J.W. and C.E. Braun. 1997. Longterm changes in sage grouse Centrocercus urophasianus populations in western North America. Wildl. Biol. 3:229-234.
Connelly, J.W., W. J. Arthur, and O.D. Markham. 1981. Sage grouse leks on recently disturbed sites. J. Range Manage. 34:153-154.

Connelly, J.W., W.L. Wakkinen, A.D. Apa, and K.P. Reese. 1991. Sage grouse use of nest sites in southeastern Idaho. J. Wildl. Manage. 55:521-524.

Crowley, C.M. and J.W. Connelly. 1996. Sage grouse population and habitat trends in Southeastern Idaho and Southwestern Montana. Unpub. Rep., Idaho Dept. of Fish and Game, Pocatello, Ida. 205pp.

Dalke, P.D., D.B. Pyrah, D.C. Stanton, J.E. Crawford, and E.F. Schlatterer. 1963. Ecology, productivity and management of sage grouse in Idaho. J. Wildl. Manage. 27:811-841.

Daubenmire, R. 1959. A canopy coverage method of vegetation analysis. Northwest Sci. 33:43-64.

Daubenmire, R. 1968. Ecology of fire in grasslands. Pp. 209-266 In: Advanced Ecological Research. Vol 5. Ed. J.R. Crogg. Acacademic Press, New York.

Drut, M.S., J.A. Crawford, and M.A. Gregg. 1994a. Brood habitat use by sage grouse in Oregon. Great Basin Nat. 54:170-176.

Drut, M.S., W.H. Pyle, and J.A. Crawford. 1994b. Technical note: diets and food selection of sage grouse chicks in Oregon. J. Range Manage. 47:90-93.

Dunn, P.O. and C.E. Braun. 1986. Summer habitat use by adult female and juvenile sage grouse. J. Wildl. Manage. 50:228-235.

Fischer, R.A. 1994. The effects of prescribed fire on the ecology of migratory sage grouse in southeastern Idaho. Ph.D. Thesis, Univ. of Idaho. Moscow, Ida.

Fischer, R.A., K.P. Reese, and J.W. Connelly. 1996. Influence of vegetal moisture content and nest fate on timing of female sage grouse migration. Condor 98:868-872.

Gates, R.J. 1985. Observations of the formation of a sage grouse lek. Wilson Bull. 97:219-221.

Hair, J.R., J.F. Rolph, E. Anderson, R.L. Tatham, and W.C. Black. 1995. Multivariate Data Analysis with readings. $4^{\text {th }}$ ed. PrenticeHall, Englewood Cliffs, N.J.

Harniss, R.O. and R.B. Murray. 1973. Thirty years of vegetal change following burning of sagebrush-grass range. J. Range. Manage 26:322-325.

Johnson, G.D. and M.S. Boyce. 1990. Feeding trials with insects in the diet of sage grouse chicks. J. Wildl. Manage. 54:89-91.

Klebenow, D.A. 1969. Sage grouse nesting and brood habitat in Idaho. J. Wildl. Manage. 33:649-662.

Klebenow, D.A. and G.M. Gray. 1968. Food habits of juvenile sage grouse. J. Range Manage. 21:80-83.

Klott, J.H. and F.G. Lindzey. 1990. Brood habitats of sympatric sage grouse and Columbian sharp-tailed grouse in Wyoming. J. Wildl. Manage. 54:84-88.

Martin, N.S. 1970. Sagebrush control related to habitat and sage grouse occurrence. J. Wildl. Manage. 34:313-320.

Martin, R.C. 1990. Sage grouse response to wildfire in spring and summer habitats. M.S. Thesis. Univ. of Idaho. Moscow, Ida.
Musil, D.D., K. P. Reese, and J.W. Connelly. 1994. Nesting and summer habitat use by translocated sage grouse (Centrocercus urophasianus) in central Idaho. Great Basin Naturalist 54:228-233.

Patterson, R.L. 1952. The sage grouse in Wyoming. Sage Books, Denver, Colo.

Peterson, J.G. 1970. The food habits and summer distribution of juvenile sage grouse in central Montana. J. Wildl. Manage. 34:147-155.

Peterson, J.G. 1995. Ecological implications of sagebrush manipulation. Montana Fish, Wildlife and Parks, Project W-101-R-2, Helena, Mont.

Pyle, W.H. and J.A. Crawford. 1996. Availability of foods of sage grouse chicks following a prescribed fire in sagebrush-bitterbrush. J. Range Manage. 49:320-324.

Rickard, W.H. 1970. Ground-dwelling beetles in burned and unburned vegetation. J. Range Manage. 23:293-294.

Robertson, M.D. 1991. Winter ecology of migratory sage grouse and associated effects of prescribed fire in southeastern Idaho. M.S. Thesis. Univ. of Idaho. Moscow, Ida.

Rothenmaier, D. 1979. Sage grouse reproductive ecology: breeding season movements, strutting ground attendance and site characteristics and nesting. M.S. Thesis, Univ. Wyoming, Laramie, Wyo. 97pp.

SAS Institute Inc. 1988. SAS/STAT User's Guide, Release 6.03 Edition. SAS Institute Inc., Cary, N.C.

SPSS Inc. 1992. SPSS/PC+. Advanced Statistics, version 5.0, Ed. Marija J. Norusis/SPSS Inc.

Sveum, C.M., W.D. Edge, and J.A. Crawford. 1998. Nesting habitat selection by sage grouse in southcentral Washington. J. Range Manage. 51:265-269.

Tisdale, E.W. and M. Hironaka. 1981. The sagebrush-grass region: A review of the ecological literature. Bull. 33. Moscow, Idaho. For. Wildl. and Range Exp. Sta.

Wakkinen, W.L. 1990. Nest site characteristics and spring-summer movements of migratory sage grouse in southeastern Idaho. M.S. Thesis, Univ. of Idaho. Moscow, Ida.

Wallestad, R.D. 1971. Summer movements and habitat use by sage grouse broods in central Montana. J. Wildl. Manage. 35:129-136.

Wallestad, R.D. and D. Pyrah. 1974. Movement and nesting of sage grouse hens in central Montana. J. Wildl. Manage. 38:630-633.

Wallestad, R.D., J.G. Peterson, and R.L. Eng. 1975. Foods of adult sage grouse in central Montana. J. Wildl. Manage. 39:628-630.

Winward, A.H. 1985. Fire in the sagebrushgrass ecosystem-The ecological setting, pp 2-6. In: Sanders, K., J. Durham, [and others] (eds.), Rangeland Fire Effects: a symposium; Proceedings. Boise, Ida.

Wright, H.A. 1985. Effects of fire on grasses and forbs in the sagebrush-grass communities, pp. 12-22 In: Sanders, K., J. Durham, [and others] (eds.) Rangeland Fire Effects - proceedings of a symposium. USDI Bur.of Land Manage., Idaho State Office and Univ. of Idaho. 1985. Boise, Ida.

Zar, J.H. 1984. Biostatisitcal Analysis. 2nd ed. Prentice-Hall, Englewood Cliffs, N.J. 